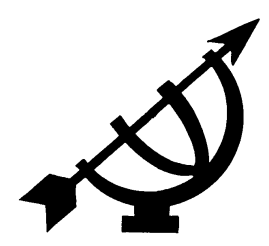

\title{
The need for more Christian counsellors
}

\author{
F.J. Pretorius \& K.H. van As \\ Department of Secondary School Teacher Education \\ Faculty of Education \\ University of South Africa \\ PRETORIA \\ E-mail: pretofj@unisa.ac.za \\ vaskh@unisa.ac.za
}

\begin{abstract}
The need for more Christian counsellors

More and more people become victims of or are affected by crime that is seemingly running rampant in the world. The existing support services cannot cope with the number of people in need of help. Christian counsellors can and should assist in this regard because they have much to offer, such as compassion and love. Christian counselling has a place and role to play in society with its ultimate goal being the facilitation of spiritual growth.
\end{abstract}

The perceived problem is the fact that there are few trained Christian counsellors and a lack of acceptance of such counsellors by authorities and the community. The suggested solution is that the church (as the body of Christ) should assume a more prominent role in rectifying the situation, by helping to change the perceptions about the role Christian counsellors can play, and by improving their training.

Opsomming

Die behoefte aan meer Christenberaders

Meer en meer mense word die slagoffers of word geraak deur misdaad wat klaarblyklik die wêreld beïnvloed. Bestaande ondersteuningsdienste kan nie werklik aan al die behoeftes van mense in nood voldoen nie. Christenberaders kan en behoort in hierdie verband hulp te verleen aangesien hulle baie het om te bied, byvoorbeeld empatie en liefde. Christelike berading het 'n plek en 'n rol om te vertolk in die gemeenskap met die uiteindelike doel om geestelike groei te bemiddel.

Die waargenome probleem is die feit dat daar te min opgeleide Christenberaders is en dat Christenberaders nie die nodige aanvaarding geniet deur die owerhede en die gemeenskap self nie. Die voorgestelde oplossing is dat die kerk (as die liggaam van Christus) 'n meer prominente rol moet speel om die aangeleentheid reg te stel deur byvoorbeeld die opleiding van 
beraders te verbeter, en te help om die persepsie oor Christenberaders en die taak wat hulle het om te vervul, te verander en reg te stel.

\section{Introduction}

In a world perpetuated by crime, natural disasters, global diseases (HIV/AIDS) and drugs, death is becoming a commonplace occurrence even for children. The result of this situation is that increasingly more people, and especially children, have become the victims of crime and abuse and are in dire need of help and counselling. Tan (1991:17) acknowledges this problem and indicates that there are many people in congregations and Christian institutions that have been hurt and who need help, but find it almost impossible to admit their concerns. This is mostly due to the absence of someone who is prepared to listen and care. Furthermore, their personal beliefs (or disbeliefs) make them feel guilty and they become afraid of others judging their beliefs. Tan (1991:21) states that we are living in a world where things are getting worse, emotional and psychological problems are increasing and we can no longer afford to pretend that these problems do not exist (see also Stone, 2001:3-4).

According to Benner (1992:8-10), pastors find it very difficult to cope with the increasing demand for counselling. Some pastors spend an average of six to eight hours per week counselling. Benner (1992:10) cites research which concluded that only $13 \%$ of the pastors who participated in the survey felt adequately prepared for their counselling responsibilities. This situation results in frustration and unfulfilment.

It is in the context of problems, needs and trauma that the

- (lay) Christian counsellor in particular, should be willing to assist with love, possible solutions and understanding.

- The church in general (both in terms of the local church and as the body of Christ), as a caring community, also has an important role which cannot be ignored (Stone, 1993:88; 2001:23).

\section{Purpose and problem statement}

This article aims at justifying the need for more (lay) Christian counsellors to be trained to primarily address the spiritual needs of people experiencing personal problems. In the light of Christian doctrine, the human being comprises body, soul and spirit (1 Thess. 5:23). It can thus be assumed that there is a difference between the aim and purpose of a Christian counsellor and that of a psychiatrist or psychologist, mainly defined by the emphasis each places on different aspects of being 
human (Benner, 1992:33-34). We should recall the point made by Solomon (1973:20) who argues that the help Christians are supposed to provide is effectively blocked because this role has been assumed by mental health professionals. Benner (1992:25) suggests that part of the problem lies with the (wrong) perception people have of pastors or the church. Some people regard their problems as too mundane or secular to be treated by a religious professional. There is also a lack of trust in Christian counselling and its effectiveness, even among Christians themselves.

Even if these problems can be overcome, a shortage of "trained" Christian counsellors exists (Tan, 1991:14). This situation can be attributed to the lack of a demand for such counsellors, and subsequently a lack of appropriate training courses. Most problems including trauma (rape, HIV/AIDS, molestation and drugs) have usually been attended to by ministers/pastors or school psychologists. According to Stone (2001: 16) most people try to solve their problems by themselves, without intervention of any kind. This situation is drastically changing because of the fact that between $13 \%$ and $14,2 \%$ (between 6 and 6,5 million) South Africans are HIV/AIDS infected and need counselling (Beeld, 2002-1204; see Anon., 2002b). This article will try, inter alia, to indicate that there are alternative ways and solutions to address the problems regarding the shortage of trained counsellors and the negative attitude that prevails against them. In this regard Lyall (2001:2) can be quoted: "New challenges must be faced, new skills and attitudes developed, 'to equip God's people for work in his service'."

Furthermore, this article argues that professional counselling alone cannot adequately address contemporary societal issues such as traumatised victims and other personal problems. More Christians are needed to attend to and counsel those in need. Allowing Christian counselling its rightful place in society because of the role it has to play in meeting certain human needs may form part of the solution. Clinebell (quoted in Stone, 2001:82) refers to this aspect when he argues: "Pastoral caregivers and other religious leaders in all faith traditions have unique and crucial roles to play in helping to heal God's living earth."

\section{Christianity and psychology}

Crabb (1985:27-29) makes the noteworthy statement that if psychology has something to offer, the Christian counsellor should take note of such information. Many people assume that Scripture has no relevance for emotional problems. Scripture, however, does address emotional and mental aspects such as guilt, anxiety, resentment, uncontrolled appetite, lack of self-acceptance, feelings of personal shortcoming, insecurity, 
misguided priorities, and selfishness. Scripture is rooted in the viewpoint that man has been created as spirit, soul and body (see also Solomon, 1973:28-31).

Kirwan (1984:25) argues that the Christian world-view goes beyond the scientific world-view and that the Christian can legitimately make use of and build upon the findings of secular scientists. In his book Christianity and psychology, Kirwan mentions four counselling perspectives (views), that is an un-Christian view; a spiritualised view; a parallel view and an integrated view. According to Kirwan (1984:30) the integrated view entails an understanding that God is the author of both revelation and reason; all truth is ultimately part of an unified or integrated whole: "The integrated view stresses not only the scriptural message concerning sin and salvation, but also the cultural mandate that God has given us to replenish and master the earth" (Kirwan, 1984:30).

One must be careful not to ignore what the science of psychology can tell us about human nature. Hurding (1992:6) is of the opinion that we must guard against the assumption that all the truth needed for the most effective counselling is contained in Scripture. One should also take note of what Murphy has to say when he states that there are non-Christians who possess great skills in the diagnosis and treatment of mental health problems:

Many are compassionate and indefatigable in their drive to refine the understanding and treatment of the biological and emotional causes of depressive illnesses. These physicians have helped develop diagnostic tools which can be used by counsellors to understand better what is really wrong with the people to whom we minister (Murphy, 1996:448).

Smith (2000:6) argues against ignoring and marginalising all psychological theories and methods simply because there is no Biblical model for such. He cautions, however, that counselling approaches and methods that are contrary to Biblical teachings should be avoided (Smith, 2000:6).

Benner (1992:15-17) makes a distinction between pastoral counselling and other forms of Christian counselling, and clearly distinguishes between pastoral counselling and clinical counselling. Benner (1992:24) argues that there are two perspectives in counselling, namely a spiritual and a psychological one. One perspective is not superior to the other and both are valuable. "... [T] he training of ministers provides a unique perspective, it equips them to see people spiritually and understand their pilgrimage and present struggles in the light of their relationship to God" (Benner, 1992:17). 
Christian counselling, based on the Word of God, can stand "on its own feet" and has a place and role to play in society (Lyall, 2001:76). Christian counselling does not yet, however, have its rightful place as a source of help nor the recognition it should or could have. It is in this regard that Tan in his book: Lay Counseling1: Equipping Christians for a helping ministry (1991) makes out a case for the need for lay Christian counselling ministries. Also Collins in his book How to be a people helper (1995), emphasises the role of the "lay Christian counsellor" by stating the following: "The layman, especially the Christian layman, must take greater responsibility in meeting the needs of those who seek solace, friendship, or counsel" (Collins, 1995:viii).

\section{A Biblical basis for lay counselling}

Tan (1991:24) points out that 1 Peter 2:5 and 9 teach that all Christians belong to the universal priesthood of believers and are called to minister one another to achieve the ultimate goal of maturity in Christ (see Eph. 4). Tan (1991:26) also emphasises the call to lay counselling as a specific ministry as well. In Galatians 6:2 Paul gives a directive to all Christians to get involved in a burden-bearing or "restoring" ministry to fellow believers (see also Clinebell quoted in Stone, 2001:83-84). Other Biblical passages such as Romans 15:14, Colossians 3:16 and 1 Thessalonians 5:14 also direct all believers to be involved in admonishing, encouraging or helping one another.

Lindgren and Shawchuck (1984:13) state that the "... empowering of laity and clergy to become active co-workers as God's people is the key to a vital church tomorrow". They continue by saying that the high calling of the church is to minister in God's name. This calling is to "laity and clergy alike, to all of God's people ... All are called to be God's ambassadors to minister in his name" (Lindgren \& Shawchuck, 1984:16). Willingness is an essential element in Christian counselling.

Wright (1996:6) agrees to a great extent with Lindgren and Shawchuck when he states that the future of pastoral care lies largely in the hands of the laity. From what he has seen and experienced, the church has not yet begun to tap its full potential in this respect. He further states: "We simply help people to recreate their true selves and experience the glorious liberty of the children of God" (Wright, 1996:48).

1 American spelling in titles of publications and quotes from American sources not changed. Elsewhere the British spelling is used. 
Counselling is an activity of pastoral care and is part of the pastoral ministry (Benner, 1992:14-15). A pastoral ministry is usually an extended ministry involving various tasks and roles. This implies that the pastor per se, does not always have the time and means to help all those who are in need. This is where the ministry of laity comes in. In the words of Stone (1993:89): "Laypersons doing crisis work are a natural extension of the church's network of care." This has resulted, according to Tan (1991:14) in the considerable growth that lay counselling has shown in recent years. It has become a significant part of not only the contemporary health scene, but it also occupies an important place in Christian ministries.

While we acknowledge all the different roles and concepts of counselling such as pastoral counselling, Christian counselling and church counselling, the emphasis is on the role of the lay Christian counsellor, within the broader context of pastoral or Christian counselling. The place to begin a Christian approach to counselling is to be found in the Bible (Collins, 1995:17).

\section{Defining (lay Christian) counselling}

Counselling constitutes a relationship between two (or more) people. According to Childs (1990:82) the word "counselling" means to consult; that is: to seek advice, to deliberate, or to counsel and it has the function of both aiding and clarifying the diagnostic process and therefore facilitating the chiselling process. Collins (1995:29) defines counselling as "... being a helping relationship between two or more people". Lyall (2001:13) elaborates on this when he states that Christian counselling comprises:

That activity which seeks to help people towards constructive change and growth in any and every aspect of their lives. The aim is to achieve this through a caring relationship with agreed boundaries, according to Biblical assumptions, aims and methods practised within a framework of Christian commitment, insight and values.

According to Hurding (1992:63) counselling is that activity "... which aims to help others towards constructive change in any or every aspect of life through a caring relationship, which has agreed boundaries and lays due emphasis on psychological mechanisms". Wright (1996:42) defines counselling as a "... relationship through which one person seeks to help another to help himself or herself and grow to greater maturity in the process. So counselling is essentially a relationship not a technique, or even primarily a skill". 
The authors of this article are inclined, however, to believe that the following definition is best suited. Collins (quoted in Tan, 1991:39) defines counselling as a "... relationship between two or more persons in which one person (the counsellor) seeks to advise, encourage and/or assist another person or persons (the counselee[s]) to deal more effectively with the problems of life". In essence, (lay) counselling is about helping and uplifting the other person to change and become a better person. This is a role that the lay Christian counsellor can and should fulfil to relieve the counselling burden on pastors and ministers.

\section{Some (lay) Christian counselling models}

Regarding counselling models, Adams (1981:4-5) states unequivocally that Christian counselling and therefore the lay Christian counsellor, have much to offer to those in need, because the lay Christian counsellor:

- has the exciting and satisfying advantage of doing counselling in which he can see the results of the Holy Spirit transforming lives through the ministry of His Word;

- has hope (and love) to offer;

- is solution-orientated, not problem-orientated.

The question, however, remains: What are Christian counsellors trying to change? Is it changing the way a person feels or are counsellors simply trying to eliminate the symptoms? Crabb (1985:131), in trying to answer these questions, states the following: "If we are clear that we want to introduce changes which will draw a person closer to God, whether the immediate feelings are positive or negative, we can evaluate what we should try to change." Lester and Stone (quoted in Stone, 2001:58) are quite clear when they state that counsellors are there to change and give hope because they (the counsellors) represent God who is "... both with us and out front of us calling, inviting, even challenging us to move into this future". According to Hurding (1992:125) the long term aim of (Christian) counselling is to change a person to become mature in Christ, while the intermediate aim is to change the present.

It can be asked if there is a single accepted model for Christian counselling. It would be difficult to point out "a" model for there are various models that can be used. One of the more acceptable models we believe, is Kirwan's (1984:147-148) Christian model for counselling which is based on the principle of imparting a sense of belonging. According to Kirwan there are three basic elements or stages in Christian counselling, that is: (1) imparting a sense of belonging, (2) edification and (3) service. These three elements "build on one another". Kirwan (1984:120-121) 
stresses that one should realise that this model resembles God's approach to Adam after the fall: God called man and said "where are you" and did not use the "there you are"-approach. Too many counsellors think they have immediate biblical answers for everyone; they tend to say "there you are", before they know what the real problem is. The best way is to ask "where are you? I want to understand what your problem really is".

A second model that is gaining acceptance is the theophostic approach of Smith (2000:5): "Theophostic Ministry is a method of bringing people to the place where they can receive freeing truth from the Lord Jesus." Culberson (2000:1-107) in his book Caring for God's people discusses other theories and methods of Christian counselling in great detail, such as the family systems theory and the narrative counselling theory. One of the most recent models on Christian counselling is called Brief Pastoral Counseling. This kind of counselling is advocated by Stone (2001) in his book Strategies for Brief Pastoral Counseling. This model aims at getting the same results (or better) in a shorter period of counselling as before (Stone, 2001:91-104).

Tan, in his book Lay counseling: Equipping Christians for a helping ministry (1991) discusses a model for lay Christian counsellors which should be taken note of. He discusses issues such as the need for lay counselling and the selection, training, supervision and evaluation of lay counsellors. What makes this model viable is that Tan identifies certain criteria for each of these categories. Tan also addresses potential pitfalls in lay counselling, such as lack of motivation and effectiveness, as well as burnout, sexuality and ethics.

Taylor (1991:8-11) explains what he calls the "metanoia model" of counselling. The word metanoia is the Greek word for changing one's mind or attitude. There are three stages in handling the problems of the counsellee according to this method, namely: (1) exploring, (2) understanding and (3) acting. The counsellor makes use of the stages of (1) presence, (2) proclamation and (3) guidance. This model can, according to Taylor (1991:4), be utilised by both lay and ordained Christian pastors and beginners alike.

Each one of these and other "models" need careful evaluation. The final choice would depend on circumstances and criteria such as the person(s) in need and the availability of Christians willing to be trained and equipped for counselling. It is suggested that the model used by Tan for lay Christian counsellors may form a suitable framework for a training model for Christians to become lay counsellors. 


\section{Other important principles or aspects regarding Christian counselling}

One of the most vital concepts of Christian counselling is "forgiveness". Every Christian counsellor of stature should emphasise the aspect of forgiveness because forgiveness brings healing and each person who is hurt needs forgiveness by himself, of himself, of others and by God (Lee, 1979:111). Forgiveness comes from the Greek word aphiemi (apo = "from" and hieme = "to send"). This concept of "to send from" or "to let go" is the essence of forgiveness. Hurding (1992:131) states: "There is no doubt that the ability to forgive and accept forgiveness is one of the hallmarks of maturity and it is a fundamental goal in counseling" (see also Gill, 1994:187).

It must always be borne in mind that a human being consists of body, soul and spirit. While it may happen that, for instance in a rape case, the body needs medical attention, the soul (mind, will and emotions) and the spiritual side will need to be attended to. Stone and Clements (1991:2830) agree with this viewpoint and state that in the past the emphasis of healing and counselling was on the body and the mind but the spirit was mostly ignored. A lack of spiritual growth, due to personal problems, has to be addressed. The answer to this problem can be found in Christian counselling which deals with the whole person.

In conjunction with this argument, one must agree with Murphy who has a word of caution in stating that Christian counsellors must be wise and should never make diagnoses about counsellees that go beyond their range of experience and knowledge: "An undiscerning counselor is a dangerous counselor, but so is an ignorant one. If knowledge is available, God expects us to search for it" (Murphy, 1996:448).

Crabb (1985:16) further elaborates on the purpose of Christian counselling when he states that it is frighteningly easy to assist a person to reach an unbiblical goal. It is our responsibility as fellow members of the body (of Christ) to continually remind and exhort one another to: “... keep in view the goal of all true counselling: to free people to better worship and serve God by helping them to become more like the Lord. In a word, the goal is "maturity" (Crabb, 1985:16). Clinebell (quoted in Stone, 2001:77-81) emphasises the need for counsellors to realise that counselling should involve cultivating healing and nurturing the wholeness of those who receive our care. This wholeness according to Clinebell (quoted in Stone 2001:81) lies, for example, in the spirit, mind, body, love, as well as in playfulness and joy. 
According to Collins (1995:5-7) counselling must take place within the boundaries of discipleship because it falls within the scope of the great commission (Matt. 28:19-20). A disciple is someone who is mature and has the three characteristics of obedience, love and fruifulness. Hurding (1992:113) regards maturity as the culmination of love. Love implies (1) the love of God (Matt. 22:38) (2) love for others (Matt. 22:39 and 1 John 3:16-17) and (3) love for oneself (see also Rom. 13:9-10 and Matt. 5:4348).

To understand the purpose of (lay) Christian counselling one needs to go one step further and refer to Maslow's "Theory of needs" (Bergh \& Theron, 1999:170). According to Maslow's theory people have five basic levels of needs, i.e. the levels of physical, security, love, purpose and self-actualisation (self-expression) needs. To a certain degree Kirwan (1984: 41) agrees with this when he indicates that according to Genesis 2-3 and Romans 1:

- God has created us with spiritual and social needs;

- good interpersonal relationships (with God and other people) are necessary to fulfil those needs. If those needs are not met,

- we will tend to become spiritually, psychologically and emotionally disorientated.

A problem starts when one or more aspects of this process is interfered with such as unattainable goals, external circumstances, fear of failure, crime and abuse or even physical disabilities. These aspects lead to frustration and frustration leads towards guilt and guilt towards resentment and resentment towards anxiety. When people do not reach their goals they start feeling insecure and worthless. Then the admission comes that they feel worthless and they experience guilt (Taylor, 1991: 69). It becomes a reality in the mind (soul). This is the state people reach before they, for example, become depressed and eventually commit suicide. Some people may use unethical behaviour or even sin in their lives to fulfil their needs and to reach their goals (see also Crabb, 1985:113-115).

In some courses and seminars in the "world outside", especially in the business world, people try to motivate the workforce to meet this last basic need, i.e. self-actualisation. The core of these courses emphasises the self; that you must believe and trust in yourself, in the power of the mind and the individual. This perspective differs completely from the Christian or biblical perspective where the Christian is taught to put all his/her trust in the Lord, to be humble and lay down the self, the flesh. Every person who is counselled must be helped to understand this 
concept and in most cases a complete mind set change is needed before a person becomes completely free from the bondage of the self (self-will) and of being self-centred.

Each of us has been programmed in his or her unconscious mind to believe that happiness, worth, joy, - all the good things of life - depend upon something other than God. Our flesh ... has resounded happily to the world's false teaching that we are sufficient to ourselves, that we can figure out a way to achieve true personal worth and social harmony without first kneeling at the cross of Christ (Crabb,1985:86).

In a strong statement Crabb (1985:76) argues that in order to be welladjusted, one needs to reach the stage of self-actualisation. Before reaching this stage ones personal and physical needs must first be met and then: "If personal needs can be met only in relationship with a personal God, then only a Christian has the resources to reach the fifth stage, to actualise himself, and therefore to be truly well adjusted" (Crabb, 1985:76). A word of caution here would be appropriate: one must realise that Christian counselling is not an "instant recipe" or a guarantee for instant success, but is an ongoing and sometimes a slow process towards a possible solution(s).

\section{Some important requirements a Christian counsellor should adhere to}

This article departs from the point of view that a Christian counsellor, when being approached by a person in need of help and counselling regarding personal problems, will not and may not refuse such assistance. This all boils down towards being "compassionate" (Stone, 1993: 21) - a well-known concept, but the essence and application of the concept has been negated.

The practice of compassion is the practice of ministry. Compassion means ministry. It is not simply sympathy or the expression of wellmeaning good intention. Compassion means getting involved in another's life for healing and wholeness (Purves, 1989:17).

Purves regards "compassion" as a ministry of presence. To be present for another is to be available for him/her. It is to relate to another with all of one's attention and energy (Purves, 1989:38-39). If Christians have compassion and understand what the concept entails, then they possess the basic qualification they need to become a Christian counsellor (see also Taylor, 1991:86). To be compassionate to others, according to Stone (1996:xi-xii), is to be "... there with them, to hurt with them, and to feel with them". 
Rogers (quoted in Wright, 1996:44) states that (lay Christian) counsellors, "... need to be genuine characters who accept others and who show empathy ...". Pastoral care covers the reality that it is the "... province of both ordained pastors and responsible lay people, and indicates the importance of the collective aspects, such as overall Church strategy, the resolving of group conflicts, and communal issues on, amongst others, housing, unemployment and conservation" (Hurding, 1992:45).

Crabb (1985:15) states the following regarding the requirements of a (lay) Christian counsellor: "... the more I abide in Christ, the more I will enjoy the pleasures available in fellowship with God". He continues by stating that a counsellor's overriding goal must be in every circumstance: "... to respond biblically, to put the Lord first, to seek to behave as $\mathrm{He}$ would want me to" (Crabb, 1985:15). A Christian counsellor must inter alia be a spiritually mature Christian i.e. a person with a personal relationship with Jesus Christ and with knowledge of basic biblical principles (see Tan, 1991:87-90).

We must also take note of the following inspiring words of Adams (1981:2) when he states:

Many times, after ten hours of counseling, I have returned to my home happier, more excited about the Bible, and actually feeling more rejuvenated than when I began in the morning. Biblical counseling doesn't leave one morose; indeed, it can be one of the greatest encouragements you will ever experience.

It is very important that more should be done in this area, in developing lay counsellors' training programmes to meet these needs, including special cross-cultural counselling skills (see also Tan, 1991:210).

\section{Lay counselling beyond the local church}

Maybe it is appropriate to point out that one must not see lay counselling as being restricted to the local church only. According to Tan (1991:208209) it is important to realise that there are various other organisations (so-called parachurch organisations) that are in need of lay counsellors, for example "Youth for Christ", "Operation Mobilisation", "Campus Crusade" and also retirement and nursing homes that have a need in this regard. In the South African context the "Jeugjaar vir Christus", an outreach programme for youths, also offers opportunities.

What is needed is a fresh approach towards counselling and specifically Christian counselling. It should be conducted by Christians in the community under proper supervision. An example of a supervisory body is the South African Association for Pastoral Work (Beeld, 2002-01-26; see 
Anon., 2002a). The point of departure for Christian counselling and the training of Christian counsellors should be from a Christian viewpoint and the Word of God. The Word of God has much to offer regarding knowledge pertaining the human nature (see also Stone, 2001:24).

\section{Conclusion and recommendations}

One cannot but conclude that presently a need exists for more (lay) Christian counsellors in the community - counsellors who will have compassion and an empathetic attitude towards people with personal problems. Psychologists and pastors alone cannot cope with the increasing demand for (spiritual) help. There is place and a need for more lay Christian counsellors in South Africa because Christian counselling has something to offer to the body, mind and spirit of people. Christian counselling is also able to meet the needs of people in trauma or those suffering from personal problems. This need exists across cultural boundaries. The authors of this article agree with Tan's (1991: 227-228) statement:

I believe that many more churches or congregations, parachurch organizations, and mission boards will become involved in a more systematic and organized ministry of lay caring and counseling because it is biblically based and commanded by our loving Lord.

It is also very important that the church (locally and as the body of Christ) must accept the responsibility of addressing the situation regarding counselling. The church should reach out to people in need and become involved in Christian counselling per se. The church and all Christians should start thinking differently about Christian counselling. Counselling could and should be done by both ordained and lay Christians, who are willing and have experienced a "call on their life". Maybe a complete paradigm shift will be necessary when thinking about Christian counselling, the role of the church (as the body of Christ) and every Christian in this regard. This concept of lay counselling is still somewhat "new" in South Africa and needs promoting as a way of helping those in need in this "rainbow nation".

It is imperative that the opportunity be created by the authorities (all role players in the public and private sector), or preferably by the church, to train and develop those who are willing to become Christian counsellors. This would entail that the necessary instruments and curriculum for the training of lay Christians be put in place, and that Christian counsellors be given official recognition as soon as possible with the responsibility, co-ordination and control that accompany such acknowledgement. Various levels and forms of training could be implemented, for example on both a formal and informal level, as well as in a practical way such as 
in-service-training or under the mentorship of a pastor or Christian psychologist.

\section{Bibliography}

ADAMS, J.E. 1981. Update on Christian Counseling. Vol 1 and 2. Ministry Resources Library. Grant Rapids. MI : Zondervan.

ANON. 2002a. Beroepsraad vir pastorale terapeute kan seksuele misbruik keer. Beeld: 12, Jan. 26.

ANON. 2002b. Minder in SA het MI-virus, toon navorsing. Beeld: 5, Des. 4.

BENNER, D.G.1992. Strategic Pastoral Counseling: A Short Term Structured Model. Michigan : Baker Book House.

BERGH, Z.C. \& THERON, A.L. 1999. Psychology in the Work Context. Oxford: Oxford University Press.

CHILDS, B.H. 1990. Short Term Pastoral Counselling: A Guide. Nashville : Abington.

COLLINS, G.R. 1995. How to Be a People Helper. Wheaton : Illinois.

CRABB, L. 1985. Effective Biblical Counselling. Glasgow : Marshall Pickering.

CULBERSON, P. 2000. Caring for God's People. Minneapolis : Fortress.

ENOCH, M.D. 1983. Healing the Hurt Mind: Christian Faith and Clinical Psychiatry. London : Hodder \& Stoughton.

GILL, M. 1994. Free to Love: Sexuality and Pastoral Care. London : Harper Collins. HURDING, R. 1992. The Bible and Counselling. London : Hodder \& Stoughton.

KIRWAN, W.T. 1984. Biblical Concepts for Christian Counseling. A Case for Integrating Psychology and Theology. Grand Rapids, Michigan : Baker Book House.

LEE, R.S. 1979. Principles of Pastoral Counselling. London : SPCK.

LINDGREN, A.J. \& SHAWCHUCK, N. 1984. Let My People Go: Empowering Laity for Ministry. 4th ed. Nashville : Abington.

LYALL, D. 2001. Integrity of Pastoral Care. Wiltshire, GB : Cromwell.

MURPHY, E.F. 1996. The Handbook for Spiritual Warfare: Revised and updated edition. Nashville: Thomas Nelson.

PURVES, A. 1989. The Search for Compassion: Spirituality and Ministry. Louisville, Kentucky : John Knox Press.

SMITH, E.M. 2000. Beyond Tolerable Recovery. 4th ed. Campsbellville, Kentucky : Family Care Publishing.

SOLOMON, C.R. 1973. Counseling with the Mind of Christ: The Dynamics of Spirituotherapy. New Jersey : Fleming H. Revel.

STONE, B.P. 1996. Compassionate Ministry: Theological Foundations. NY : Orbis Books.

STONE, H.W. \& CLEMENTS, W.M. 1991. Handbook for Basic Types of Pastoral Care and Counseling. Nashville : Abington.

STONE, H.W, 1993. Crisis Counseling. (Rev. ed.) Minneapolis : Fortress.

STONE, H.W. (Ed). 2001. Strategies for Brief Pastoral Counseling. Minneapolis : Fortress.

TAN, S. 1991. Lay Counseling: Equipping Christians for a Helping Ministry. Michigan : Zondervan.

TAYLOR, C.W. 1991. The Skilled Pastor: Counseling as the Practice of Theology. Minneapolis : Fortress.

WRIGHT, F. 1996. Pastoral Care Revisited. London : SAM. 


\section{Key concepts:}

Christian counselling/counsellors

lay Christian counsellors

Biblical basis for lay counselling

principles of (lay) Christian counselling

\section{Kernbegrippe:}

Christelike berading/beraders

leke-Christenberaders

Bybelse grondslag vir lekeberaders

beginsels vir (leke-) Christenberading 
